\section{Heat Requirement for Blooming and Leafing in Peach}

\author{
I. Citadin ${ }^{1}$ \\ Centro Federal de Educação Tecnológica do Paraná, Cx. P. 571, 85503-390, \\ Pato Branco, PR, Brazil
}

M.C.B. Raseira ${ }^{2}$ and F.G. Herter ${ }^{3}$

Embrapa Clima Temperado, Cx. P. 403, 96001-970, Pelotas, RS, Brazil

\author{
J. Baptista da Silva ${ }^{4}$ \\ Universidade Federal de Pelotas, Cx.P. 345, 96001-900, Pelotas, RS, Brazil
}

Additional index words. ecodormancy, anthesis, growing degree hours, Prunus persica

\begin{abstract}
Differences in heat requirements for blooming and leafing were investigated in peach [Prunus persica $($ L.) Batsch] using artificially chilled excised shoots and potted trees. 'Della Nona' and 'BR-1' have high heat requirements; 'Planalto', 'Sunlite', and 'Eldorado' are intermediate; and 'Precocinho' and 'Riograndense' have low heat requirements. Prolonged chilling enhanced leafing more than blooming. Flower and vegetative buds have different heat requirements during ecodormancy.
\end{abstract}

The climatic conditions of the peach-producing areas in Brazil are highly variable. They are characterized by warm winters with great temperature fluctuations, typical of subtropical regions. In several areas, late frosts in August and September are frequent. The cultivars better adapted to southern Brazil have low chilling requirements ( 150 to 500 chilling hours). Once the chilling requirement is satisfied, they start blooming. Early blooming increases the likelihood of damage by late winter or early spring frosts. The time of full bloom depends on two factors: the chill units necessary to complete rest, and the growing degree hours Celsius $\left(\mathrm{GDH}^{\circ} \mathrm{C}\right)$ required after endodormancy to reach full bloom (Raseira, 1986; Richardson et al., 1975).

Zegbe-Domingues et al. (1994) reported differences between years and peach genotypes for heat requirement for full bloom. Observations at Byron, Ga., indicated that the late blooming 'Pi Tao' (PI62602) had a low chilling requirement. Likewise, selections from Aguascalientes, Mexico, have low chilling requirements but are late blooming in temperate regions (Scorza and Okie, 1990). These observations suggest the involvement of a genetic component for the amount of heat required for blooming.

Received for publication 8 Sept. 1999. Accepted for publication 3 Aug. 2000. This research was supported in part by the Embrapa Clima Temperado and CAPES (Fundação Coordenação de Aperfeiçoamento de Pessoal de Nível Superior). We thank Dr. James N. Moore for his cooperation and assistance with English. The cost of publishing this paper was defrayed in part by the payment of page charges. Under postal regulations, this paper therefore must be hereby marked advertisement solely to indicate this fact.

${ }^{1}$ Graduate Student.

${ }^{2}$ Adviser, Fruit Breeder; to whom reprint requests should be addressed. E-mail address: bassols@ cpact.embrapa.br

${ }^{3}$ Researcher.

${ }^{4}$ Statistics Professor.
Knowledge of the genetic tendencies for peach bloom date would facilitate the development of cultivars adapted to subtropical climates. Genotypes with high chilling requirements could not be grown there, but genotypes with delayed bloom due to a high heat requirement during ecodormancy would be suitable. The objective of this investigation was to determine the differences in heat requirement for time of blooming and leafing among seven peach cultivars.

\section{Materials and Methods}

Two sets of experiments were conducted during 1997 and 1998 at the Empresa Brasileira dePesquisa Agropecuária(EMBRAPA)/Centro de Pesquisa Agropecuária de Clima Temperado (Temperate Climate Agricultural Research Center), Pelotas, Rio Grande do Sul, Brazil (latitude $32^{\circ} 45^{\prime} \mathrm{S}$ and longitude $52^{\circ} 30^{\prime} \mathrm{W}$ ).

Experiment I. Field-collected shoots. Oneyear-old shoots, 25 to $30 \mathrm{~cm}$ long, of six peach cultivars, 'Precocinho', 'Riograndense', 'BR1', 'Planalto', 'Della Nona', and 'Eldorado', and 1998, before chilling accumulation had begun. 'Delicioso' was included in 1998 to compare its heat requirement with that of its offspring, 'BR-1' and 'Della Nona'. Groups of 10 shoots were placed in flasks containing 150 $\mathrm{mL}$ distilled water $+3 \%$ sucrose $+0.3 \%$ aluminum sulfate and artificially chilled at $2{ }^{\circ} \mathrm{C}$ for 400 or $800 \mathrm{~h}$. Each week the water was replaced and the basal ends of the shoots were cut. After the chilling treatment, the shoots were placed in a phytotron and subjected to an 8 -h photoperiod $\left(22.5 \mu \mathrm{mol} \cdot \mathrm{m}^{-2} \cdot \mathrm{s}^{-1}\right)$ at $24 \pm 1$ ${ }^{\circ} \mathrm{C}$. The basal ends of the shoots were cut (Citadin et al., 1998), and flower and vegetative budbreak were observed three times a week. The numbers of buds that reached the balloon or green tip stages were recorded.

The number of $\mathrm{GDH}^{\circ} \mathrm{C}$ accumulated was determined (Richardson et al., 1975), beginwere collected at the beginning of May in 1997 ning when the shoots were taken to the phytotron, and continuing until $5 \%$ of the flower buds had reached the balloon stage and $10 \%$ of the leaf buds had reached the green tip stage (in each bundle of 10 shoots). Ten percent was considered as the beginning of bloom and leafing, because this percentage is conventionally adopted for field observations in the EMBRAPA peach collection. However, flower buds on detached shoots dropped easily; therefore, $5 \%$ was used. The base temperature for heat accumulation was $4.5^{\circ} \mathrm{C}$.

Chilling hours (Weinberger, 1950) were used instead of chill units (Utah model; Richardson et al., 1974) because the temperature was maintained at $2 \pm 1{ }^{\circ} \mathrm{C}$, so as to prevent $\mathrm{GDH}^{\circ} \mathrm{C}$ accumulation during the chilling treatments.

The experimental design was a completely randomized block with three replications, each represented by 10 twigs collected from one tree, and two factors: cultivar and chilling hours. Analysis of variance (ANOVA) was calculated on $\mathrm{GDH}^{\circ} \mathrm{C}$ for each year of the test. Means were compared using Duncan's test $(P$ $\leq 0.05)$.

Experiment II. Trees in containers. Nursery trees of the peach cvs. Precocinho, Riograndense, Eldorado, BR-1, Sunlite, Planalto, and Della Nona were potted in 0.02$\mathrm{m}^{3}$ (20-L) containers with 2 solarized soil : 1 sand (by volume). They were grown under natural conditions for 1 year, and were watered periodically with Hoagland's modified nutrient solution. On 23 Apr. 1998, the young trees were moved to a cold chamber and artificially chilled for 400 or $800 \mathrm{~h}$ at $2{ }^{\circ} \mathrm{C}$ in darkness. Trees were then transferred to a greenhouse, and forced under a natural photoperiod $(\approx 10 \mathrm{~h})$ and temperatures between 21 and $25^{\circ} \mathrm{C}$. Flower and vegetative budbreak was observed three times per week and the percentage of open flowers and growing vegetative buds were recorded. Accumulation of $\mathrm{GDH}^{\circ} \mathrm{C}$ required for beginning of bloom and full bloom (10\% and 50\%) and full leafing (50\% of vegetative buds at green tip) was calculated as in Expt. I.

The experimental design was a completely randomized factorial with three replications (except for 'Eldorado' and 'Riograndense', which were subjected to 800 chilling hours, with two replications) and two factors (cultivar and chilling hours). Analysis of variance (ANOVA) was calculated on the $\mathrm{GDH}^{\circ} \mathrm{C}$ and means were compared by Duncan's test $(P \leq$ $0.05)$.

\section{Results and Discussion}

Experiment I. Interaction of cultivar $\times$ chilling treatment was significant in 1997, but not in 1998 , in affecting $\mathrm{GDH}^{\circ} \mathrm{C}$ accumulation needed to reach $5 \%$ bloom in field-collected shoots (Table 1). Significant differences were observed among cultivars for number of $\mathrm{GDH}^{\circ} \mathrm{C}$ required to reach 5\% bloom in 1997 (Fig. 1A). The differences between the results observed in 1997 and 1998 (Fig. 1 A and B) may be due to environmental factors during the growing season. Tissue necrosis and bud 
drop were especially prevalent in 'Precocinho' and 'Riograndense' after $800 \mathrm{~h}$ of chilling in 1997 (Fig. 1A). These cultivars have low chilling requirements, and excessive chilling may have caused physiological injuries to buds and shoots.

Among the shoots chilled at $2^{\circ} \mathrm{C}$ for $400 \mathrm{~h}$ in 1997 (Fig. 1A), the cultivars BR-1 and Della Nona required the most $\mathrm{GDH}^{\circ} \mathrm{C}$ to reach $5 \%$ bloom, followed by 'Eldorado' and 'Planalto', while 'Precocinho' and 'Riograndense' had the lowest requirement. In shoots chilled for $800 \mathrm{~h}$, greater similarity among the cultivars was observed in the $\mathrm{GDH}^{\circ} \mathrm{C}$ accumulation for blooming. Only 'Riograndense' and 'Precocinho', with a low heat requirement, differed significantly from 'BR-1', 'Della Nona', 'Eldorado', and 'Planalto'. Cultivars Precocinho and Riograndense required more $\mathrm{GDH}^{\circ} \mathrm{C}$ to bloom when chilled for 800 than for 400 h, whereas 'BR-1' and 'Della Nona' required less. The $\mathrm{GDH}^{\circ} \mathrm{C}$ was not significantly different for 'Planalto' and 'Eldorado'.

In 1998, 'Delicioso', 'Della Nona', and 'BR-1' required the most $\mathrm{GDH}^{\circ} \mathrm{C}$ to reach $5 \%$ bloom. 'Eldorado' differed from all cultivars except'BR-1'. 'Planalto' and 'Precocinho' constituted a third group, followed by 'Riograndense', with the lowest $\mathrm{GDH}^{\circ} \mathrm{C}$ requirement (Fig. 1B).

The greater uniformity observed among cultivars in the 800-h treatment can be explained by Champagnat's (1989) observation that once dormancy is established, it is controlled by factors within each bud; therefore, each bud has a characteristic behavior. Thus, increasing the number of chill units does not reduce the heat requirement, as pointed out by Scalabrelli and Couvillon(1986), but increases the uniformity in chilling requirement among buds.

Note that all cultivars except 'Planalto' required <400 chilling hours (Raseira and Nakasu, 1998).

Monet and Bastard (1969, 1971) demonstrated that peach flower buds develop slowly under low temperatures, but are physiologically and biochemically active. Rapid growth resumes when temperatures rise. Thus, prolonged exposure to low temperatures prolongs the slow growth phase, thereby reducing the rapid growth phase.

'Delicioso' is one of the parents of 'BR-1' and 'Della Nona'. These three cultivars are similar in heat requirement for beginning of bloom (Fig. $1 \mathrm{~A}$ and B). The heat requirement for blooming is thus genetically controlled and heritable. 'Delicioso' is a "great-grandparent” of 'Planalto' (Table 2).

We observed that 'BR-1' had a high heat requirement for bloom, regardless of chilling hours. This explains previous observations about the adaptation of 'BR-1' to colder regions (600 h of chilling) as well as warmer regions $(\approx 200 \mathrm{~h}$ ). This cultivar is late blooming under both sets of conditions. 'Delicioso' is well-adapted to areas with $200 \mathrm{~h}$ of chilling accumulation, but its bloom period is always late. Yields of 'Della Nona' are higher in regions that have close to $400 \mathrm{~h}$ of chilling and is a late blooming (Table 2) and late ripening
Table 1. Analysis of variance for growing degree hours $\left(\mathrm{GDH}^{\circ} \mathrm{C}\right)$ to reach $5 \%$ of blooming $(1997$ and 1998$)$ and leafing (1998), in peach shoots chilled for 400 or $800 \mathrm{~h}$ at $2{ }^{\circ} \mathrm{C}$.

\begin{tabular}{|c|c|c|c|c|c|c|}
\hline \multirow{3}{*}{$\begin{array}{l}\text { Source of } \\
\text { variation }\end{array}$} & \multirow{2}{*}{\multicolumn{2}{|c|}{$\frac{1997}{\text { Blooming }}$}} & \multicolumn{4}{|c|}{1998} \\
\hline & & & \multicolumn{2}{|c|}{ Blooming } & \multicolumn{2}{|r|}{ Leafing } \\
\hline & df & MS & $\mathrm{df}$ & MS & $\mathrm{df}$ & MS \\
\hline Cultivar & 5 & $104,885,115^{* *}$ & 6 & $18,206,065^{* *}$ & 6 & $25,917,142^{* *}$ \\
\hline Chilling time & 1 & $694,197^{\mathrm{Ns}}$ & 1 & $67,976,241^{* *}$ & 1 & $287,676,342^{* *}$ \\
\hline $\begin{array}{l}\text { Cultivar } \times \\
\text { chilling time }\end{array}$ & 5 & $12,647,795^{* *}$ & 6 & $880,414^{\mathrm{Ns}}$ & 6 & $11,725,142^{* * *}$ \\
\hline Error & 22 & $1,229,458$ & 27 & 840,622 & 28 & $1,791,342$ \\
\hline
\end{tabular}

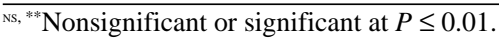
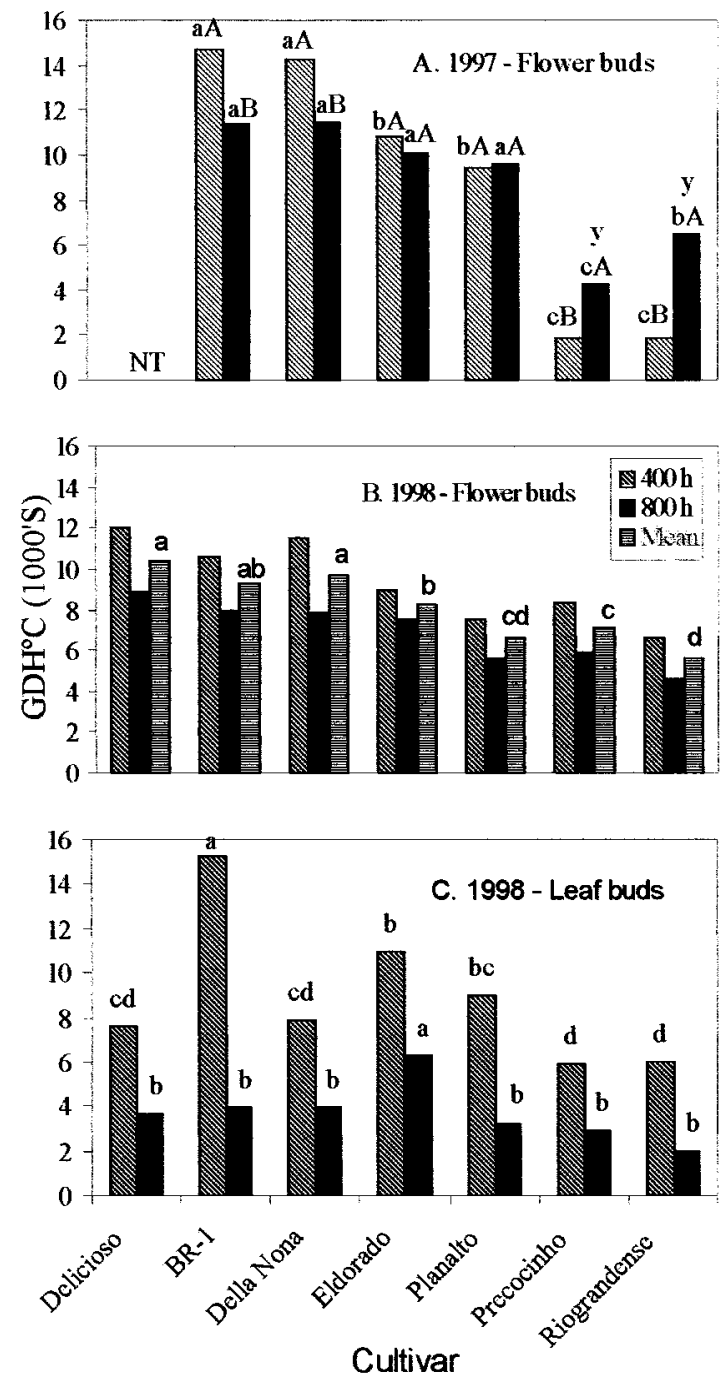

Fig. 1. Growing degree hours to reach $5 \%$ bloom (flower buds) and $10 \%$ budbreak (leaf buds) in peach shoots chilled for 400 or $800 \mathrm{~h}$ at $2{ }^{\circ} \mathrm{C}$. Mean separation among cultivars (lower-case letters) and between chilling treatment within cultivars (capital letters) by Duncan's Multiple Range Test, $P \leq 0.05$. Differences between the effects of chilling treatments on flowers buds were nonsignificant with cultivars in 1998, but were significant for the means for all cultivars. Means for $800 \mathrm{~h}$ were significantly less than for $400 \mathrm{~h}$, for leaf budbreak in 1998. ' Serious problems with necrosis and bud drop. NT $=$ Not tested.

Table 2. Parentage, chilling requirement, and average date in the field for beginning bloom and full bloom of some peach cultivars from the Southern Brazil breeding program (Raseira and Nakasu, 1998).

\begin{tabular}{|c|c|c|c|c|}
\hline \multirow[b]{2}{*}{ Cultivar } & \multirow[b]{2}{*}{ Parentage } & \multirow{2}{*}{$\begin{array}{l}\text { Chilling h } \\
\left(\leq 7.2^{\circ} \mathrm{C}\right)\end{array}$} & \multicolumn{2}{|c|}{ Avg bloom date } \\
\hline & & & First & Full \\
\hline Planalto & Coral $^{2}$ X Babcock & $400-500$ & 20 Aug. & 30 Aug. \\
\hline Della Nona & (Delicioso $\times$ Nectared 5) OP & 400 & 23 Aug. & 30 Aug. \\
\hline BR-1 & Delicioso $\times$ Panamint & $<300$ & 9 Aug. & 21 Aug. \\
\hline Eldorado & Gaudério x Serrano & 300 & $28 \mathrm{Jul}$. & 9 Aug. \\
\hline Riograndense & (Brilhante $\times$ NJ 97) OP & 300 & $30 \mathrm{Jul}$. & 11 Aug. \\
\hline Precocinho & Diamante OP & 150 & $16 \mathrm{Jul}$. & 26 Jul. \\
\hline Delicioso & Unknown & 200 & 22 Aug. & 27 Aug. \\
\hline
\end{tabular}

${ }^{2}$ Coral $=($ Delicioso $x$ Interludio $)$ open-pollinated $(\mathrm{OP})$. 
cultivar. The cultivars maintained the same relative order in heat requirement for bloom regardless of chill units received (Fig. $1 \mathrm{~A}$ and B).

Interaction of cultivar $\times$ chilling was significant in the $\mathrm{GDH}^{\circ} \mathrm{C}$ accumulation needed to reach $10 \%$ budbreak (Table 1 ). 'Precocinho' needed less $\mathrm{GDH}^{\circ} \mathrm{C}$ than did 'Riograndense', 'Delicioso', and 'Della Nona'. However, it did not differ from them when subjected to $400 \mathrm{~h}$, but differed from the other three cultivars. After $800 \mathrm{~h}$ of chilling, 'Eldorado' had the highest $\mathrm{GDH}^{\circ} \mathrm{C}$ of all cultivars (Fig. 1C). Note that 'Delicioso' required a higher $\mathrm{GDH}^{\circ} \mathrm{C}$ accumulation for bloom than for leafing.

Based on the results obtained for the beginning of blooming (Fig. $1 \mathrm{~A}$ and $\mathrm{B}$ ) and leafing (Fig. 1C), after 400 and $800 \mathrm{~h}$ at $2{ }^{\circ} \mathrm{C}$, we conclude that prolonged chilling enhances leafing more than bloom. Therefore, flower and vegetative peach buds have different heat requirements in the ecodormancy period. In years or locations where higher chilling accumulation occurs, leafing can occur before blooming. However, in years of low chilling accumulation, blooming can take place before leafing. Scalabrelli and Couvillon (1986) concluded that lateral vegetative and flower buds had similar chilling requirements. Therefore, the differences observed in time of blooming and leafing, in this experiment, can be attributed to differences in heat requirement among flower and vegetative buds.

Experiment II. Trees in containers. Cultivar $\times$ chilling interaction was again significant in the data on $\mathrm{GDH}^{\circ} \mathrm{C}$ accumulation required to reach $10 \%$ and $50 \%$ bloom (Table 3 ). Heat requirement decreased when the cultivars were submitted to $2^{\circ} \mathrm{C}$ for $800 \mathrm{~h}$ (Table 4), indicating an inverse relationship between the effects of chilling and heat accumulation on time of bloom. These results agree with those obtained with excised shoots (Fig. 1 A and B) and are in accordance with the suggestion of Spiegel-Roy and Alston (1979). According to these authors, chilling requirement during dormancy (endodormancy) of pear (Pyrus sp.) and heat requirement in after-rest (ecodormancy) are highly related to time of bloom. Both could be used as selection criteria, but selection for heat requirement alone would be effective. Felker and Robitaille (1985) found that physiological maturation of cherry (Prunus cerasus L.) buds in the fall, chilling accumulation in deep rest, and heat accumulation leading to budbreak are overlapping processes that are very difficult to separate.

'Della Nona' trees subjected to $400 \mathrm{~h}$ at 2 ${ }^{\circ} \mathrm{C}$ required the most $\mathrm{GDH}^{\circ} \mathrm{C}$ to reach $10 \%$ and $50 \%$ bloom. When subjected to $800 \mathrm{~h}$ at $2{ }^{\circ} \mathrm{C}$, this cultivar again required the most $\mathrm{GDH}^{\circ} \mathrm{C}$, but differed only from 'Riograndense' for $10 \%$ bloom and 'Sunlite', 'Planalto', 'Precocinho', and 'Riograndense' for $50 \%$ bloom (Table 4).

Cultivar $\times$ chilling interation was nonsignificant in $\mathrm{GDH}^{\circ} \mathrm{C}$ accumulation for $50 \%$ leaf budbreak (Table 3). Great uniformity was ob-

Table 3. Analysis of variance for growing degree hours to reach $10 \%$ and $50 \%$ of blooming, and $50 \%$ of leaf budbreak in peach trees chilled for 400 or 800 hours at $2^{\circ} \mathrm{C}$, in 1998 .

\begin{tabular}{|c|c|c|c|c|c|c|}
\hline \multirow{2}{*}{$\begin{array}{l}\text { Source of } \\
\text { variation }\end{array}$} & \multicolumn{2}{|c|}{$10 \%$ Bloom } & \multicolumn{2}{|c|}{$50 \%$ Bloom } & \multicolumn{2}{|c|}{$50 \%$ Leaf budbreak } \\
\hline & df & MS & df & MS & df & MS \\
\hline Cultivar & 6 & $7,479,088^{* *}$ & 6 & $15,277,754^{* * *}$ & 6 & $4,361,417^{\mathrm{NS}}$ \\
\hline Chilling time & 1 & $101,314,586^{* *}$ & 1 & $198,191,818^{* *}$ & 1 & $199,625,606^{* * *}$ \\
\hline Cultivar & & & & & & \\
\hline$\times$ chilling time & 6 & $2,438,454^{* *}$ & 6 & $7,780,150^{* *}$ & 6 & $1,684,887^{\mathrm{Ns}}$ \\
\hline Error & 24 & 581,361 & 24 & 476,748 & 24 & $1,479,480$ \\
\hline
\end{tabular}

Ns, ${ }^{* *}$ Nonsignificant or significant at $P \leq 0.01$.

Table 4. Growing degree hours to reach $10 \%$ and $50 \%$ bloom, and $50 \%$ of leaf budbreak in peach trees chilled at $2^{\circ} \mathrm{C}$ for 400 and $800 \mathrm{~h}$ in 1998 .

\begin{tabular}{|c|c|c|c|c|c|c|c|}
\hline \multirow[b]{2}{*}{ Cultivar } & \multicolumn{2}{|c|}{$10 \%$ bloom } & \multicolumn{2}{|c|}{$50 \%$ bloom } & \multicolumn{2}{|c|}{$50 \%$ leaf budbreak } & \multirow[b]{2}{*}{ Mean } \\
\hline & $400 \mathrm{~h}$ & $800 \mathrm{~h}^{\mathrm{y}}$ & $400 \mathrm{~h}$ & $800 h^{y}$ & $400 \mathrm{~h}$ & $800 \mathrm{~h}$ & \\
\hline Della Nona & $14,068 \mathrm{a}^{\mathrm{z}}$ & $8,652 \mathrm{a}$ & $17,837 \mathrm{a}$ & $9,749 \mathrm{a}$ & 9,123 & 4,389 & $6,756 \mathrm{ab}$ \\
\hline BR-1 & $12,588 \mathrm{~b}$ & $8,016 \mathrm{ab}$ & $15,282 \mathrm{~b}$ & $8,654 \mathrm{ab}$ & 10,867 & 4,658 & $7,763 \mathrm{a}$ \\
\hline Sunlite & $11,285 \mathrm{bc}$ & $7,354 \mathrm{ab}$ & $15,045 \mathrm{~b}$ & $8,120 \mathrm{~b}$ & $\mathrm{NT}^{\mathrm{y}}$ & 2,750 & --- \\
\hline Planalto & $11,129 \mathrm{bc}$ & $7,332 \mathrm{ab}$ & $12,364 \mathrm{c}$ & $8,314 \mathrm{~b}$ & 10,538 & 4,255 & 7,397 ab \\
\hline Eldorado & $10,914 \mathrm{c}$ & $8,122 \mathrm{ab}$ & $12,487 \mathrm{c}$ & $8,757 \mathrm{ab}$ & 8,012 & 4,053 & $6,033 \mathrm{ab}$ \\
\hline Precocinho & $9,499 \mathrm{~d}$ & $7,682 \mathrm{ab}$ & $10,555 \mathrm{~d}$ & $8,434 \mathrm{~b}$ & 7,693 & 3,998 & $5,846 \mathrm{~b}$ \\
\hline Riograndense & $8,449 \mathrm{~d}$ & $6,603 \mathrm{~b}$ & $9,510 \mathrm{~d}$ & $7,466 \mathrm{~b}$ & 7,567 & 3,099 & $5,333 \mathrm{~b}$ \\
\hline Means & & & & & 8,967 & $3,886^{*}$ & \\
\hline
\end{tabular}

${ }^{2}$ Mean separation within columns by DMRT, $P \leq 0.05$.

${ }^{\mathrm{y} T}=$ Not tested.

*Significantly less than value for $400 \mathrm{~h}(P \leq 0.05)$.

served in heat requirement for $50 \%$ leafing among cultivars, based on the means observed for 400 and 800 chilling hours. 'BR-1' required the highest $\mathrm{GDH}^{\circ} \mathrm{C}$ accumulation, but differed only from 'Precocinho' and 'Riograndense'. All other cultivars did not differ in $\mathrm{GDH}^{\circ} \mathrm{C}$ accumulation (Table 4).

The ending of endormancy is not a discrete, but a gradual and quantitative process, represented by a continuous increase in the speed of blooming and leafing as heat accumulation increases. This behavior varies with both genotype and environment. Chilling above the threshold requirement of a cultivar reduces heat requirement for budbreak, particularly for leaf buds, and tends to make the heat requirement of different cultivars more uniform. However, some genotypes, especially 'Della Nona' and 'BR-1', have a high heat accumulation for blooming, even when chilled for $800 \mathrm{~h}$. These genotypes can be adapted to a wider environment and can produce good crops even in years or locations when chilling accumulation is limited.

In summary, we conclude that peach cultivars differ in heat requirement for blooming: 'Della Nona' and 'BR-1' have a high heat requirement; 'Planalto', 'Sunlite', and 'Eldorado' have an intermediate requirement; and 'Precocinho' and 'Riograndense' have a low requirement. Vegetative and flower buds of peach differ in heat requirement for leafing and blooming.

\section{Literature Cited}

Champagnat, P. 1989. Rest and activity in vegetative buds af trees. Forest tree physiology. Ann. Sci. For. 46(Suppl.):9s-26s.

Citadin, I., M.C.B. Raseira, and A.C. Quezada 1998. Substrato para conservação de ramos destacados de pessegueiro, Prunus persica $\mathrm{L}$.
(Batsch). Agropecuária Clima Temperado. 1:5559.

Felker, F.C. and H.A Robitaille. 1985. Chilling accumulation and rest of sour cherry flower buds. J. Amer. Soc. Hort. Sci. 110: 227-232.

Monet, R. and Y. Bastard. 1969. Initiation florale et phénomènes de dormance chez le pêcher [Prunus persica (L.) Batsch]. Compte Rendue Acad. Sci. 268:1931-1933.

Monet, R. and Y. Bastard. 1971. Effets d'une température modérément élevée: $25^{\circ} \mathrm{C}$, sur les bourgeons floraux du pêcher. Physiol. Veg. 9: 209-226.

Raseira, M.C.B. 1986. Time of flower bud initiation and meiosis in peach cultivars differing in chilling requirement. PhD. Diss., Univ. of Arkansas, Fayetteville.

Raseira, M.C.B. and B.H. Nakasu. 1998. Cultivares: Descrição e recomendação, p. 29-99. In: A cultura do pessegueiro. Embrapa-SPI, Brasilia.

Richardson, E.A., S.D. Seeley, and D.R. Walker. 1974. A model for estimating the completion of rest of 'Redhaven' and 'Elberta' peach trees. HortScience 9:331-332.

Richardson, E.A, S.D. Seeley, D.R. Walker, J.L.M. Anderson, and G.L. Ashcroft. 1975. Phenoclimatography of spring peach bud development. HortScience 10:236-237.

Scalabrelli, G. and G.A. Couvillon. 1986. The effect of temperature and bud type on rest completion and the $\mathrm{GDH}^{\circ} \mathrm{C}$ requirement for budbreak in 'Redhaven' peach. J. Amer. Soc. Hort. Sci.111:537-540.

Scorza, R. and W.R. Okie. 1990. Peaches (Prunus persica L. Batsch). Acta Hort. 290:177-231.

Spiegel-Roy, P. and F.H. Alston. 1979. Chilling and post-dormant heat requirement as selection criteria for late-flowering pears. J. Hort. Sci. 54:115120.

Weinberger, J.H. 1950. Chilling requirements of peach varieties. Proc. Amer. Soc. Hort. Sci. $56: 122-128$

Zegbe-Dominguez, J.A; A.F. Rumayor-Rodriguez, and R.J. Campbell. 1994. Blooming time differences among seedling peach clones. Proc. Interamer. Soc. Trop. Hort. 38:127-132. 